\title{
Verification of geophysical models in Alpine permafrost using borehole information
}

\author{
Daniel S. Vonder Mühll, ${ }^{1}$ Christian Hauck, ${ }^{1}$ Frank Lehmann ${ }^{2}$ \\ ${ }^{1}$ Versuchsanstalt für Wasserbau, Hydrologie und Glaziologie, ETH Zentrum, CH-8092 Zürich, Switzerland \\ ${ }^{2}$ Institut für Geophysik, ETH Hönggerberg, CH-8093 Zürich, Switzerland
}

\begin{abstract}
At two permafrost sites in the Swiss Alps a range of geophysical methods were applied to model the structure of the subsurface. At both sites, borehole information was used to verify the quality of the model results. On the Murtèl-Corvatsch rock glacier (2700 m a.s.l.; upper Engadine) a $58 \mathrm{~m}$ deep core drilling was performed in 1987. D.c. resistivity measurements, refraction seismics, ground-penetrating radar (GPR) and gravimetric surveys allowed the shape of the permafrost table beneath the marked surface microtopography to be determined and the lateral extent of a deeper shear horizon to be established. The validity of each method was verified by the borehole information (cores, density log and temperature). A coherent model of the rock-glacier structure was developed. At the Schilthorn (2970 m a.s.l.; Bernese Oberland), it was not clear whether permafrost is in fact present. Various geophysical surveys (d.c. resistivity tomography, refraction seismics, GPR and EM-31) gave results that were not typical of permafrost environments. A $14 \mathrm{~m}$ percussion drilling revealed warm permafrost and a very low ice content. These geotechnical and geothermal data allowed reinterpretation of the geophysical results, improving modelling of ground conditions. The paper demonstrates that in the difficult terrain of Alpine permafrost, boreholes may be critical in calibration and verification of the results of geophysical methods. The most useful combinations of geophysical techniques proved to be (a) seismics with d.c. resistivity, and (b) gravimetry with GPR.
\end{abstract}

\section{INTRODUCTION}

The principal goal of geophysical surveys is to obtain information on the subsurface structure. Field measurements which apply different methods form the basis for the data processing. The result usually consists of a model of subsurface physical parameters which best fits the measurements obtained. A borehole provides an ideal verification of the model stratigraphy at one particular point, and borehole data are widely used to tune model parameters. However, the lateral extent of the layers can be investigated most efficiently by geophysical means.

Since permafrost is a thermal phenomenon, the temperature in the subsurface should be determined from surface measurements. However, geophysical surveys use other physical properties (e.g. seismic velocity, electric resistivity, dielectric impedance, density) to infer the presence or absence of permafrost. Frozen bedrock often has a low ice content, and the geophysical methods that must be applied are different to those used in surveys of ice-rich permafrost. To verify geophysical models, only direct information from boreholes can be used, and boreholes also allow measurement of the thermal regime of the particular site.

Geophysical surveys on mountain permafrost pose particular logistical and technical challenges: remote and steep terrain with marked changes in physical properties over very short distances, on the one hand, and permafrost as a thermal phenomenon, on the other hand, may to some extent limit the application and feasibility of certain geophysical techniques. Nevertheless, geophysical methods have been successfully applied to analyze permafrost distribution in mountainous areas, and to determine the depth of the permafrost table and/or the approximate thickness of the permafrost and its internal structure and ice content (e.g. Scott and others, 1979; Vonder Mühll, 1993).

However, in the case of seismic and electrical surveys, one crucial issue is the contact of the equipment (explosives, geophones and electrodes) with the ground, especially when the surface layers consist of coarse boulders with many voids (King and others, 1992). Other methods such as gravimetry, ground-penetrating radar (GPR) and electromagnetic (EM) induction are not influenced by this since they do not need direct ground contact.

Within the framework of the EU project "Permafrost and Climate in Europe" (PACE), one work package is dedicated to developing better field and interpretation techniques for a wide range of geophysical methods used for mapping and characterizing mountain permafrost. The resulting geological models are verified using information from several boreholes 15-100 m deep. In this paper, two sites, the Murtèl-Corvatsch rock glacier and the Schilthorn mountain peak, both in Switzerland, are used to illustrate subsurface modelling and its validation with reference to borehole information.

\section{FIELD SITES}

The Murtèl-Corvatsch rock glacier, upper Engadine, eastern Switzerland (Fig. 1), is one of the best-investigated creeping permafrost bodies. After the drilling in 1987, several studies provided information on: distortion of the borehole, analysis of the drilling core, snow-cover characteristics, energy 




\begin{abstract}
Fig. 1. The Murtèl-Corvatsch rock glacier with pronounced furrows and ridges in the lower part. The drill site is indicated with a circle. The line shows the general longitudinal profile on which most of the presented measurements were taken. Insert: Location of Murtèl-Corvatsch ( $M)$ and Schilthorn $(S)$ in a Swiss map.
\end{abstract}

balance, temperatures in the borehole and at the surface, geodetically and photogrammetrically determined creep behaviour, hydrology, isotopic analysis of meltwater and a number of surface geophysical surveys (Vonder Mühll, 1993; Haeberli and others, 1998). The surface consists of coarse crystalline boulders. The permafrost temperature is $-2^{\circ} \mathrm{C}$ at $14 \mathrm{~m}$ depth. Geophysical field measurements have provided data for modelling subsurface structures, and these models were validated against the borehole information. Of particular interest are:

(a) the thickness of the active layer and its shape around the strongly pronounced microtopography of furrows and ridges

(b) the depth of a so-called shear horizon, which forms the base of the creeping part of the permafrost

(c) the depth of the bedrock which outcrops at the front of the rock glacier.

This information is critical for further modelling of the morphodynamics of this rock glacier.

The Schilthorn (2970 m a.s.l.; Bernese Oberland) is an east-west-striking crest with north- and south-facing slopes. The presence of permafrost was proven at the summit when the cable-car facilities were built some 30 years ago. During the construction work, several ice lenses up to $1 \mathrm{~m}$ thick were encountered. Some years ago, a shaft was constructed to $12 \mathrm{~m}$ depth, which showed icy layers in the subsurface. In 1998, temperature readings in this shaft were close to $0^{\circ} \mathrm{C}$, but not negative (personal communication from M. Imhof, 1998). Measurements of the bottom temperature of the snow cover and d.c. resistivity soundings did not provide clear indications of the presence and the distribution of permafrost in the Schilthorn area (Imhof, 1999). After further geophysical surveys (d.c. resistivity tomography, refraction seismics, GPR and EM methods using, for example, an EM-31 device) performed at the potential site of the $100 \mathrm{~m}$ deep PACE borehole, there still remained some uncertainties concerning the presence of perennially negative ground temperatures.

The Schilthorn consists of fine-grained dark limestone schist that weathers to form quite small debris, mainly fine pebbles, in contrast to the crystalline rocks at most of the locations where geophysical investigations in Alpine permafrost have so far been made. Therefore, the physical and especially the electrical properties are quite different to coarse-debris covered surfaces, and the energy balance at the surface (insulation capacity of the snow cover; lower albedo) is also affected. Two questions were therefore of major importance at the Schilthorn site: is there a layer in the bedrock where temperatures are perennially $<0^{\circ} \mathrm{C}$ and if so, how thick is the active layer in the bedrock?

\section{GEOPHYSICAL SURVEYS}

To answer the above questions at the two target sites, different methods were applied and combined (Table 1). Where permafrost is developed in unconsolidated debris, both d.c. resistivity and seismic velocity change abruptly at the permafrost table. Thus, at both the Murtèl-Corvatsch rock glacier and the Schilthorn, the permafrost table was investigated using a small spacing between the geophones and electrodes to obtain a suitable high resolution. The change of physical properties at the shear horizon in the rock glacier and at the bedrock are characterized by density and impedance 
Table 1. Target layers/boundaries and applied geophysical methods

\begin{tabular}{lccc}
\hline Target & Method & $\begin{array}{c}\text { Murtèl-Corvatsch } \\
\text { rockglacier }\end{array}$ & Schilthorn \\
\hline $\begin{array}{c}\text { Active layer, } \\
\text { permafrost } \\
\text { table }\end{array}$ & $\begin{array}{c}\text { Refraction seismics } \\
\text { Two-dimensional d.c. } \\
\text { resistivity tomography }\end{array}$ & $\begin{array}{c}\text { Applied } \\
\text { Applied }\end{array}$ & $\begin{array}{c}\text { Applied } \\
\text { Applied }\end{array}$ \\
Shear horizon & GPR & Applied & - \\
& Gravimetry & Applied & - \\
Bedrock & GPR & Applied & Applied \\
& Gravimetry & Applied & Not applied \\
& & & \\
\hline
\end{tabular}



Fig. 2. Results of the refraction seismics on the Murtèl-Corvatsch rock glacier. The drilling (dashed line) and several shot points are indicated. The permafrost table smooths the marked relief.

contrasts, and therefore gravimetry and GPR are the most promising approaches.

\section{Position and form of the permafrost table}

\section{Murtèl-Corvatsch rock glacier}

Refraction seismics were performed in October 1990, when the active-layer thickness is greatest and hence corresponds to the position of the permafrost table. Explosives were used as the seismic source. The shape of the permafrost table beneath the pronounced compressional furrows and ridges on the rock-glacier surface was of particular interest (Vonder Mühll, 1993).

The data were processed with the generalized reciprocal method (GRM; Palmer, 1980, 1986). Calculations were conducted using two $x y$-values $(0 \mathrm{~m}$, corresponding to the plusminus method (Hagedoorn, 1959), and $5 \mathrm{~m}$ ), resulting in enhanced resolution of the refractor. Geophone spacing was $5 \mathrm{~m}$.

Seismic velocities in the top layer which consists of coarse boulders varied over a large range $\left(700-1000 \mathrm{~m} \mathrm{~s}^{-1}\right)$. This value is critical because of the depth conversion from time to length unit. The refractor below with typical velocities of $3400-3700 \mathrm{~m} \mathrm{~s}^{-1}$ is continuous and represents the ice-rich permafrost layer. Results of the survey line oriented in the rock-glacier flow direction indicate that the permafrost table is on average $2 \mathrm{~m}$ deep: beneath the furrows the permafrost table was very shallow, sometimes even at the surface $(0-1 \mathrm{~m})$, while the depth increased beneath each ridge (Fig. 2). Hence, the permafrost table smooths the marked microrelief.

The two-dimensional resistivity tomography was performed by a multi-electrode system (ABEM Lund) with 30 electrodes ( $5 \mathrm{~m}$ spacing) in a Wenner array. Sponges soaked with salt water were used to reduce the contact resistivity between the electrodes and the big boulders on the rock-glacier surface. The measured apparent resistivities were inverted using the software package RES2DINV (Loke and Barker, 1996). Due to the limited array length, the penetration depth was only some $15-20 \mathrm{~m}$. Figure 3 shows the resulting model of a longitudinal profile over the tongue of the Murtèl-Corvatsch rock glacier.

From the model results, the difference between the icerich permafrost of the rock glacier and the permafrost-free terrain in front is clearly seen, with specific resistivity values of up to $1 \mathrm{M} \Omega \mathrm{m}$ for the ice-rich permafrost layer and of $<10 \mathrm{~K} \Omega \mathrm{m}$ for the non-permafrost region in front of the rock glacier. The modelled permafrost layer is located at depths between $4 \mathrm{~m}$ (furrows) and $7 \mathrm{~m}$ (ridges). However, because of the rather coarse measurement grid (smallest electrode spacing $5 \mathrm{~m}$ ), the resolution of the first few metres below the surface is poor. More details of the method and the model results are given in Hauck and Vonder Mühll (1999).

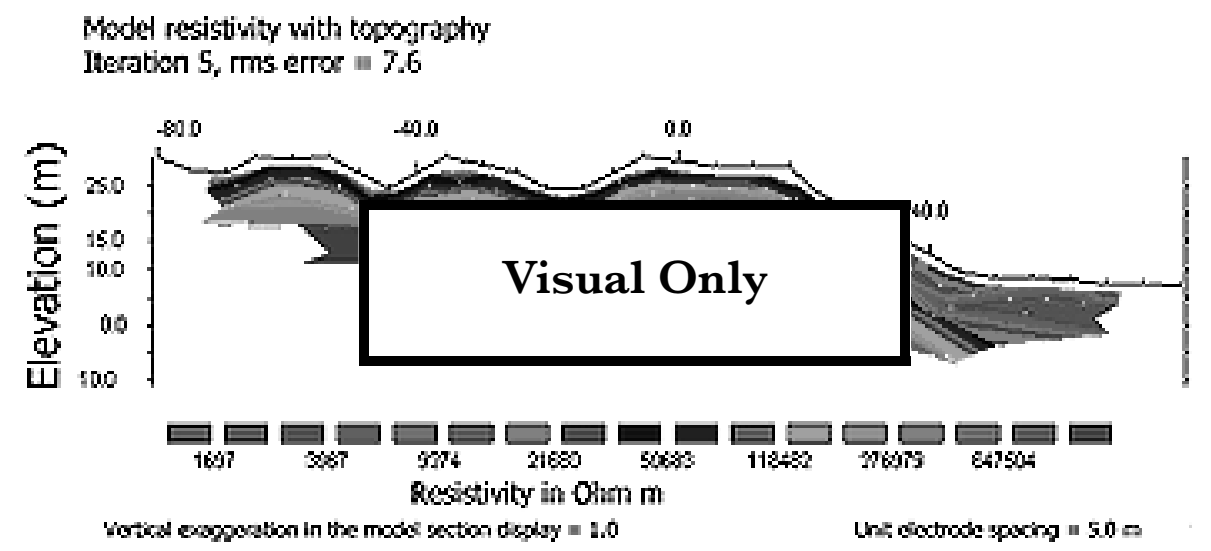

Fig. 3. Longitudinal profile of a two-dimensional d.c. resistivity tomography over the tongue of the Murtèl-Corvatsch rock glacier. Elevation and horizontal distance are given in metres relative to an arbitrary point; resistivity is contoured on a logarithmic scale. Dark areas represent high resistivities and therefore high ice content. The tongue is located between stations 0 and +15 , with a steep descent of about $25 \mathrm{~m}$ to the non-permafrost area in front of it. 




Fig. 4. Model results for three d.c. resistivity tomography profiles some 5 m apart on the Schilthorn, using $5 \mathrm{~m}$ spacing and Wenner array. The drilling is located in the centre $(0 \mathrm{~m})$ of the middle profile. Values of $<1 \mathrm{~K} \Omega \mathrm{m}$ represent unfrozen bedrock.

\section{Schilthorn}

The principal aim on the Schilthorn was to determine whether permafrost is in fact present. Due to the low ice content in the bedrock, a high unfrozen-water content even in the presence of permafrost, and a rather high clay content, it was difficult to determine the exact phase composition (solid/liquid) of water in the subsurface materials.

The refraction seismic lines were measured in August 1998 using 24 geophones with a $5 \mathrm{~m}$ interval and explosives as source. For comparison, one line was recorded in the south-facing, permafrost-free side of the Schilthorn ridge.

Bedrock with seismic velocity values of approximately $5000 \mathrm{~m} \mathrm{~s}^{-1}$ was found at $2-4 \mathrm{~m}$ depth. The top layer representing the active layer shows velocities of $450-800 \mathrm{~m} \mathrm{~s}^{-1}$, which is typical for unfrozen weathered material. The values of the non-permafrost line were $1500 \mathrm{~m} \mathrm{~s}^{-1}$ for the weathered upper layer and $3000-3500 \mathrm{~m} \mathrm{~s}^{-1}$ for the bedrock with a refractor depth of $2-5 \mathrm{~m}$. This indicates a smaller P-wave velocity for the unfrozen bedrock.

As mentioned above, d.c. resistivity values recorded at the Schilthorn are about one to two orders of magnitude lower $(2-4 \mathrm{~K} \Omega \mathrm{m})$ than on the ice-rich permafrost of the Murtèl-Corvatsch rock glacier (Fig. 3). Figure 4 shows three parallel survey lines some $5 \mathrm{~m}$ apart. The lines in the north slope ran east-west parallel to the ridge of the Schilthorn.

Modelled specific resistivity values were smallest in the centre $(1-2 \mathrm{~K} \Omega \mathrm{m})$ and significantly higher towards either end $(2-5 \mathrm{~K} \Omega \mathrm{m})$. In the centre, the uppermost $4 \mathrm{~m}$ had values close to $1 \mathrm{~K} \Omega \mathrm{m}$. These values apparently represent the active layer. Below this, the resistivities increased to a depth of $15 \mathrm{~m}(2 \mathrm{~K} \Omega \mathrm{m})$ where the values began to decrease with depth once again. It had previously been assumed that mountain permafrost had resistivity values not lower than some $10 \mathrm{~K} \Omega \mathrm{m}$ (Haeberli and Vonder Mühll, 1996). Although the relative sequence of the resistivities is typical for a permafrost site, the absolute values are too low by about one order of magnitude. This implies that on permafrost with fine-grained surface materials with a marked clay content, resistivity values can be as low as a few $\mathrm{K} \Omega \mathrm{m}$. This means that the shape of the sounding curve is very important for the interpretation, and probably an additional method (e.g. seismics) is required.

\section{Shear horizon and bedrock on Murtèl-Corvatsch rock glacier}

\section{Gravimetry}

A gravimetrical study was carried out in the area of the Murtèl-Corvatsch rock glacier, first to check the applicability of this method in Alpine permafrost, and secondly to deduce the lateral extent of both shear horizon and bedrock (Vonder Mühll and Klingelé, 1994). Measurements were corrected for latitude, elevation, topography of the surrounding terrain



Fig. 5. Results of the gravimetric modelling recorded on the Murtèl-Corvatsch rock glacier. Note that the shear horizon and the bedrock are bowl-shaped, producing an oversteepening towards the front. 


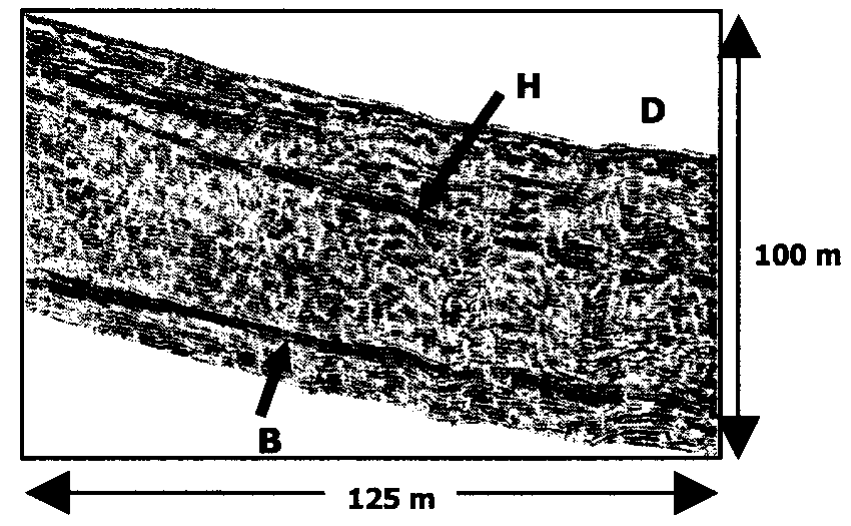

Fig. 6. Georadar dataset recorded across the Murtèl-Corvatsch rock glacier. $D$ is the drill site. Elevation corrections have been applied. Reflection H originates from an internal shear zone, and $B$ from the bedrock.

and Earth tide. This allowed inferences to be made concerning the density variation within the subsurface material. The gravity anomaly $\Delta g$ is given by the difference between the measured and the calculated gravity of the model.

In the present case, the creeping permafrost represents the disturbing body, which has a lower density than the bedrock because of the ice contained within it. The density structure of the rock glacier for modelling four different layers was derived from the $\gamma-\gamma \log$ (density log) of the borehole 2/1987 (Fig. 5). In addition, the following aspects were included in compiling the model: refraction seismics (Barsch, 1973) for the thickness of the active layer, the general morphology of the creeping permafrost and the outcrop of bedrock on the eastern and northern sides of the rock glacier.
As a first step, modelling was performed in two-and-ahalf dimensions (Cady, 1980), where the disturbing body is approximated by polygons along the cross-section extending laterally (perpendicular to the profile). The resulting density distributions along the profiles were then used to produce a three-dimensional geometry of each layer. A bedrock density of $2.76 \mathrm{Mg} \mathrm{m}^{-3}$ was assumed.

Figure 5 shows the modelled layers in a cross-section along the rock glacier. The thickness of the layers is greatest near the drill site, where the supersaturated permafrost (ice content $>40 \%$ by volume, i.e. the volume of the voids) is about $25 \mathrm{~m}$ thick. The bedrock surface beneath the rock glacier is bowl-shaped and is obviously overdeepened. This clearly causes the compressing flow and hence the pronounced ground-surface topography with its marked ridges and furrows. Towards the upper end, the shear horizon and the bedrock ascend towards the valley.

\section{GPR}

Georadar may be described as "echo sounding with EM waves". An EM wave field generated at a transmitter antenna propagates through the medium of interest and is reflected or scattered from subsurface impedance contrasts. Georadar has the potential to provide high-definition images of the shallow subsurface.

Georadar data were recorded across a permafrost-rich zone within the Murtèl-Corvatsch rock glacier. The dataset was corrected for elevation (Lehmann and others, 1998).

Clearly visible are two strong reflection bands, one from an internal shear zone $\mathrm{H}$ and one from the bedrock surface B (Fig. 6). The internal shear zone separates an upper mobile permafrost layer from a lower stationary one. Depth estimation with georadar was verified with the nearby borehole.
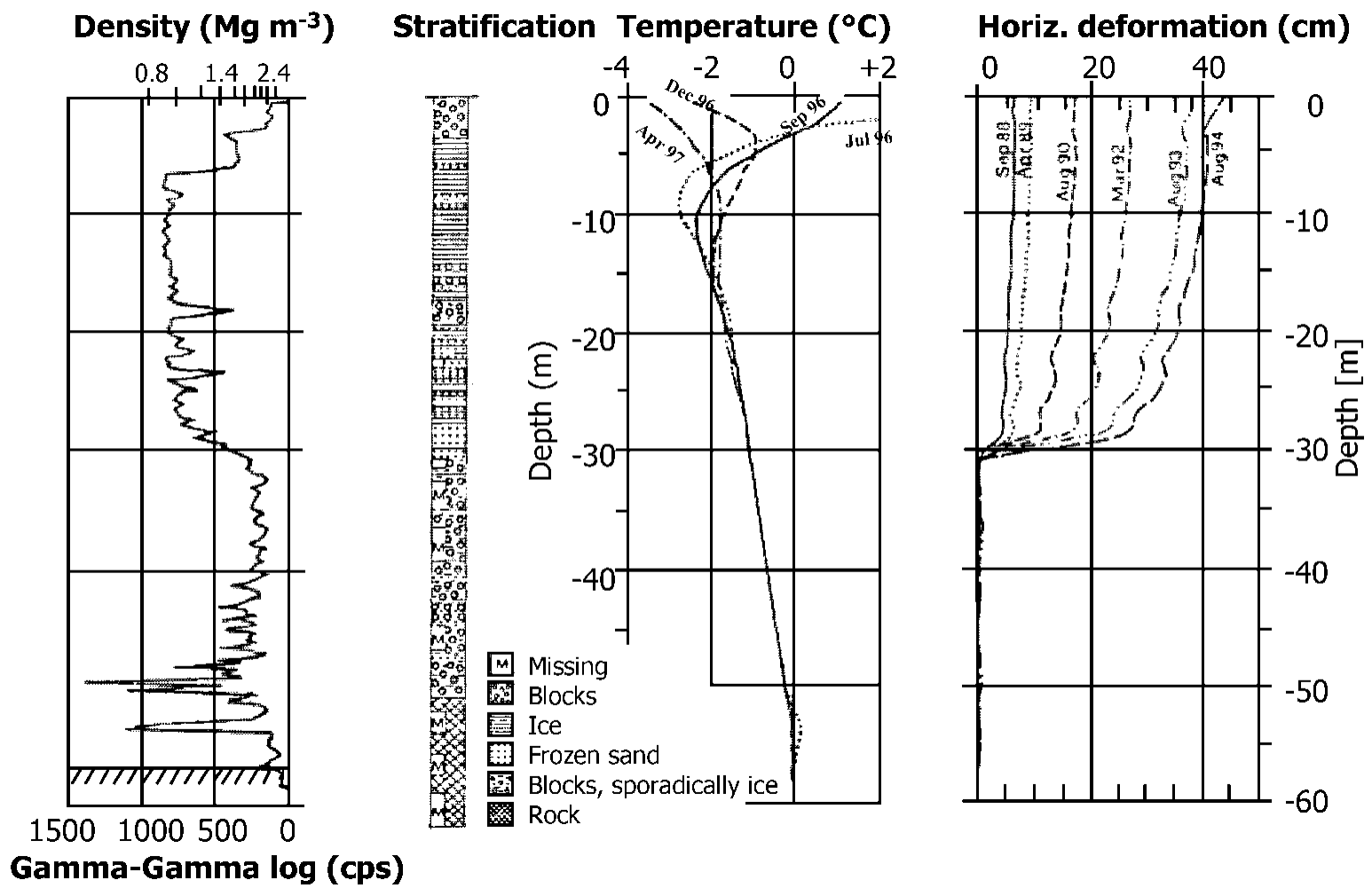

Fig. 7. Principal borehole results from the drilling 2/1987 on Murtèl-Corvatsch. The rock glacier is structured as follows: beneath the active layer there are ice-rich layers to $30 \mathrm{~m}$ depth, where at the shear horizon $4 \mathrm{~cm} a^{-1}$ of movement occur. Below, in structured permafrost the ice content is 30-40\%. Bedrock is reached at $57 \mathrm{~m}$ depth. 
Depths of bedrock and shear horizon differ by $<1$ m compared to the borehole and gravimetry.

\section{DRILLINGS}

\section{Results of borehole 2/1987 on Murtèl-Corvatsch rock glacier}

The main results from borehole 2/1987 can be summarized as follows (cf. Haeberli and others, 1998). Beneath the permafrost table, the rock glacier consists mainly of two layers (Fig. 7): an upper layer with an extremely high ice content $(90-100 \%$ by volume), and a lower one consisting of coarse blocks with icefilled pores (around $40 \%$ by volume) but almost completely without fine rock particles. The deformation of the borehole was determined by a slope-indicator tube (horizontal displacement) and magnetic rings (vertical displacement). According to the borehole-deformation measurements and photogrammetric analysis, the surface velocity at the drill site is about $6 \mathrm{~cm} \mathrm{a}^{-1}$. The main zone of shearing (about $4 \mathrm{~cm} \mathrm{a}^{-1}$ ) is in the transition zone between the two main permafrost layers, at 28-30 $\mathrm{m}$ depth, with the upper (supersaturated) layer obviously undergoing steady-state creep and overriding the non-deforming (structured) lower layer (Wagner, 1992). This shear horizon controls the creep behaviour of the rock glacier. The slope-indicator measurements continued until 1994, when it became impossible for the inclinometer to pass down to the deformed-borehole liner tube. Vertical deformation occurs mainly at 25-30 m depth, and the layer immediately above the shear horizon is shortened by roughly $1 \mathrm{~cm} \mathrm{a}^{-1}$. The temperature-measurement series showed that mean annual surface temperature is approximately $-2.5^{\circ}$ to $-3.0^{\circ} \mathrm{C}$. The thermal thickness of the active layer is roughly $3.4 \mathrm{~m}$. Seasonal temperature variations at $20 \mathrm{~m}$ depth are $<0.1^{\circ} \mathrm{C}$, with a "mid-term" temperature increase from $-1.8^{\circ}$ to $-1.4^{\circ} \mathrm{C}$ which occurred between 1991 and 1995.

\section{$14 \mathrm{~m}$ deep percussion drilling on the Schilthorn}

To check whether the Schilthorn site is located in the belt of present permafrost, a shallow borehole (14 $\mathrm{m}$ deep) was drilled in mid-October 1998. The cuttings pulled to the surface were slightly wet to $5 \mathrm{~m}$ depth; below this they were generally dry. No ice layers were encountered during the drilling.

A plastic tube containing a string with 17 thermistors was installed, measuring temperatures at increasing intervals with depths. Temperature readings showed that the active layer reaches down to $5 \mathrm{~m}$ depth, indicating that below the weathered layer the uppermost few metres of the bedrock thaw seasonally as well. At greater depths, temperature values decrease and reach $-0.7^{\circ} \mathrm{C}$ at $14 \mathrm{~m}$ depth (Fig. 8).

\section{DISGUSSION AND GONGLUSION}

Due to numerous difficulties in applying geophysical methods in mountain permafrost terrain, it is important to combine complementary methods. In addition, borehole information as shown in the example of the Murtèl-Corvatsch rock glacier offers an excellent opportunity to verify and adapt the models which result from the interpretation of the field geophysical measurements.

Data processing of d.c. resistivity tomography and gravimetry uses inversion models with iteration algorithms to

\section{Schilthorn, Nov 1998}

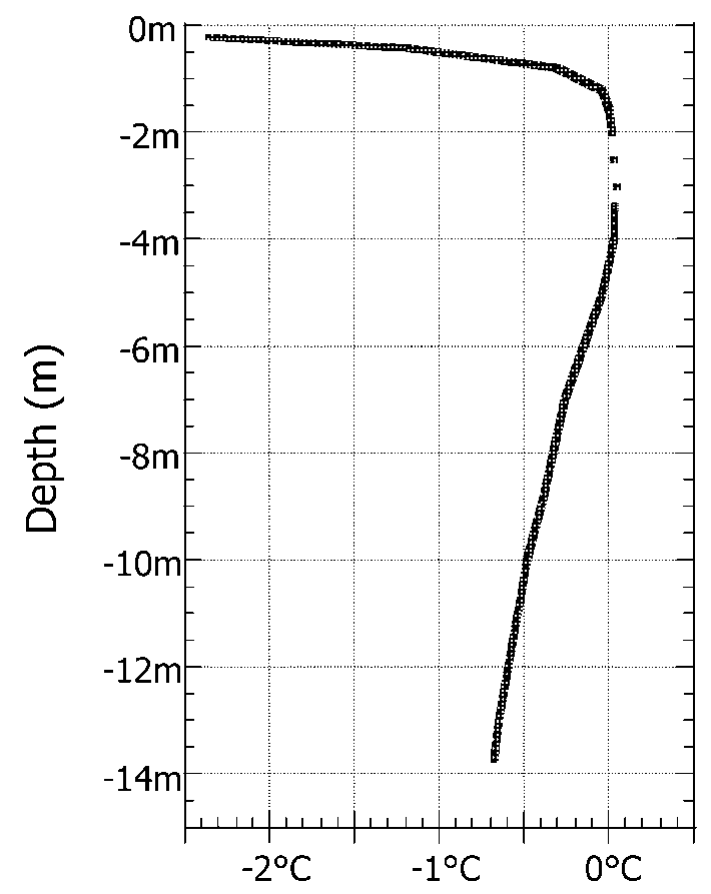

Fig. 8. Temperature profile from the Schilthorn (November 1998, left). On the Schilthorn the active layer reaches down to $5 \mathrm{~m}$ depth, as the zero curtain zone (isothermal layer at this date) between 1 and $5 \mathrm{~m}$ indicates. Thus, the layer of seasonal thawing beneath the weathered layer comprises the uppermost few metres of the bedrock as well.

establish a best fit to the measured data. One-dimensional refraction seismics and GPR apply models in a more implicit sense. Therefore the combinations of (a) seismics with d.c. resistivity and (b) gravimetry with GPR, supplemented with information from a borehole, are regarded as ideal.

At Murtèl-Corvatsch, the permafrost table modelled from the d.c. resistivity tomography could be confirmed by several means: refraction seismics, borehole temperatures and the observation in the field that one can see the permafrost ice sometimes in the furrows but never on top of the ridges. Shape and depth of the shear horizon and the bedrock determined by gravimetry and GPR match very well. In addition, the bowl-shaped overdeepening explains why in the seismics no refracted signals from the bedrock were recorded.

At the Schilthorn, temperature measurements in the borehole confirmed the presence of permanently frozen bedrock, as expected from the permafrost-distribution modelling (Hoelzle and Haeberli, 1995; Imhof, 1996) and from the form of the d.c. resistivity sounding curve, although resistivities were one order of magnitude lower than presumed, because of fine-grained, clay-rich surface conditions.

The Murtèl-Corvatsch and Schilthorn sites represent two completely different types of Alpine permafrost occurrences: the rock-glacier permafrost is characterized by a medium albedo, a high ice content, coarse crystalline boulders (diameter $0.1-20 \mathrm{~m}$ ) and low temperatures $\left(-2.0^{\circ} \mathrm{C}\right.$ at $10 \mathrm{~m}$ depth), while on the Schilthorn a low albedo, very little ice, fine-grained dark pebbles (diameter $0.1-0.3 \mathrm{~m}$ ) and higher temperatures $\left(-0.5^{\circ} \mathrm{C}\right.$ at $10 \mathrm{~m}$ depth $)$ are found. 
This makes these two sites good contrasting examples indicating the parameter ranges for the various geophysical methods, which in turn allows improved modelling. The best suited methods can thus be evaluated. For example, on the low-resistivity bedrock of the Schilthorn, the penetration depth of the $50 \mathrm{MHz}$ GPR signals was limited to roughly $5 \mathrm{~m}$, while on the high-resistivity Murtèl-Corvatsch rock glacier, bedrock was detected at up to $>50 \mathrm{~m}$ depth.

The geophysically based models of subsurface structure at Murtèl-Corvatsch, plus the various parameters that were measured, provide critical data for modelling flow characteristics of creeping permafrost and assessment of geotechnical behaviour of frozen ground. In general terms, geophysical techniques offer the potential for spatial mapping of permafrost occurrence, particularly where ground-truthing is available from borehole evidence.

\section{ACKNOWLEDGEMENTS}

The drilling through the Murtèl-Corvatsch rock glacier and most fieldwork there was funded by a special grant from ETH Zürich (0230.70). The PACE project is funded by the European Union (ENV4-CT97-0492) and the Swiss Government (97.0054). Many field helpers assisted in performing the geophysical surveys. Thanks are due to C. Harris (Cardiff) for valuable discussions and to $\mathrm{K}$. Meldrum for editing the English.

\section{REFERENCES}

Barsch, D. 1973. Refraktionsseismische Bestimmung der Obergrenze des gefrorenen Schuttkörpers in verschiedenen Blockgletschern Graubündens, Schweizer Alpen. Z. Gletscherkd. Glazialgeol., 9(1-2), 143-167.

Cady, J.W. 1980. Calculation of gravity and magnetic anomalies of finitelength right polygonal prisms. Geophysics, 45(10), 1507-1512.

Haeberli, W. and D. Vonder Mühll. 1996. On the characteristics and possible origins of ice in rock glacier permafrost. Z. Geomorphol., Supplementband 104, 43-57.

Haeberli, W., M. Hoelzle, A. Kääb, F. Keller and D. Vonder Mühll. 1998. Ten years after drilling through the permafrost of the active rock glacier
Murtèl, eastern Swiss Alps: answered questions and new perspectives. Université Laval. Centre d'Études Nordiques. Collection Nordicana 57, 403-410.

Hagedoorn, J. G. 1959. The plus-minus method of interpreting seismic refraction sections. Geophys. Prospect., 7 (2), 158-182.

Hauck, C. and D. Vonder Mühll. 1999. Using DC resistivity tomography to detect and characterise mountain permafrost. In 61st European Association of Geoscientists and Engineers (EAGE) Conference, 7-11 June 1999, Helsinki, Finland. Proceedings. Houten, European Association of Geoscientists and Engineers, 2-15.

Hoelzle, M. and W. Haeberli. 1995. Simulating the effects of mean annual air-temperature changes on permafrost distribution and glacier size: an example from the Upper Engadin, Swiss Alps. Ann. Glaciol., 21, 399-405.

Imhof, M. 1996. Modelling and verification of the permafrost distribution in the Bernese Alps (western Switzerland). Permafrost and Periglacial Processes, 7(3), 267-280.

Imhof, M. 1999. Beiträge zur Modellierung der Permafrostverbreitung in den Berner Alpen unter besonderer Berücksichtigung der Schilthorngruppe. (Ph.D. thesis, Universität Bern.)

King, L., A. P. Gorbunov and M. Evin. 1992. Prospecting and mapping of mountain permafrost and associated phenomena. Permafrost and Periglacial Processes, 3(2), 73-81.

Lehmann, F., D. Vonder Mühll, M. van der Veen, P. Wild and A. G. Green. 1998. True topographic 2-D migration of georadar data. In 11th Annual Symposium on the Applications of Geophysics to Environmental and Engineering Problems (SAGEEP), Chicago, U.S.A. Extended abstracts. Wheat Ridge, CO, Environmental and Engineering Geophysical Society, 107-114.

Loke, M. H. and R. D. Barker. 1996. Rapid least-squares inversion of apparent resistivity pseudosections using a quasi-Newton method. Geophys. Prospect., 44(2), 131-152.

Palmer, D. 1980. The generalized reciprocal method of seismic refraction interpretation. Tulsa, OK, Society of Exploration Geophysicists.

Palmer, D. 1986. Refraction seismics. Section 1: Seismic exploration. In Helblig, K. and S. Treitel, eds. Handbook of geophysical exploration. Vol. 13. London, etc., Geophysical Press.

Scott, W. J., P.V. Sellmann and J. A. Hunter. 1979. Geophysics in the study of permafrost. In Proceedings. Third International Conference on Permafrost, 10-13 July 1978, Edmonton, Alberta. Vol. 2. Ottawa, Ont., National Research Council of Canada, 93-115.

Vonder Mühll, D. S. 1993. Geophysikalische Untersuchungen im Permafrost des Oberengadins. Eidg. Tech. Hochschule, Zürich. Versuchsanst. Wasserbau, Hydrol. Glaziol. Mitt. 122.

Vonder Mühll, D. S. and E. E. Klingelé. 1994. Gravimetrical investigation of ice-rich permafrost within the rock glacier Murtèl-Corvatsch (upper Engadin, Swiss Alps). Permafrost and Periglacial Processes, 5(1), 13-24.

Wagner, S. 1992. Creep of Alpine permafrost investigated on the Murtèl rock glacier. Permafrost and Periglacial Processes, 3(2), 157-162. 